\title{
EVALUATION OF ANTICONVULSANT ACTIVITY OF MIMOSA PUDICA ROOT LINN IN SWISS ALBINO MICE
}

\author{
PRATHIMA C., SHASHIKUMARA, THIPPESWAMY T., JAYANTHI M. K. \\ Dept. of Pharmacology, JSS Medical College (A Constituent College of JSS University), Mysore \\ Email: samsruthia@gmail.com
}

Received: 15 Mar 2016 Revised and Accepted: 22 Jul 2016

\section{ABSTRACT}

Objective: To evaluate the anticonvulsant activity of ethanolic extract of Mimosa pudica root (EMPR) in experimental mice models.

Methods: Ethanolic extract of root parts of Mimosa pudica (EMPR) was prepared by a continuous method using soxhlet apparatus. EMPR in doses of $1000,2000 \mathrm{mg} / \mathrm{kg}$ body wt along with valproate were administrated to albino mice by oral route and anti-epileptic activity was assessed by maximal electroshock (MES) and pentylenetetrazole (PTZ) induced seizure models. Abolition of tonic hind limb extension phase and an increase in seizure latency period, when compared to control group, were taken as a measure of protection in MES and PTZ induced convulsion models respectively.

Results: EMPR in the dose of 1000 and $2000 \mathrm{mg} / \mathrm{kg}$ body wt of mice showed significant anti-epileptic property in both MES and PTZ induced seizure models. There was a significant abolition of tonic hind limb extension phase in MES model. There was also a significant increase in seizure latency period in PTZ induced seizure model.

Conclusion: Results suggest that ethanolic extract of Mimosa pudica roots possess significant anti-epileptic activity. Further investigations are required to determine its active constituents and also its antiepileptic mechanism of action.

Keywords: Epilepsy, Mimosa pudica root extract, MES, PTZ model

(C) 2016 The Authors. Published by Innovare Academic Sciences Pvt Ltd. This is an open access article under the CC BY license (http://creativecommons. org/licenses/by/4. 0/) DOI: http://dx.doi.org/10.22159/ijpps.2016.v8i9.11716

\section{INTRODUCTION}

'Epilepsy' is the commonest neuropsychiatric disorder characterized by paroxysmal cerebral dysrrhythmia, manifesting as brief episodes (seizures) of loss or disturbance of consciousness, with or without characteristic body movements (convulsions) with sensory or psychiatric phenomena [1]. There are about 50 million epileptic patients worldwide of whom up to $75 \%$ are living in the poor socioeconomic background with little or minimal access to medical services or therapy [2]

Seizures can be defined as brief episodes of signs and symptoms due to abnormal, excessive synchronous neuronal activity in the brain Epilepsy can be idiopathic or secondary to infection, neoplasm or head injury. In some case, it may be hereditary [3]. Epilepsy is a major public health issue in many nations. Despite the massive scale of the problem and much research undertaken therapy of epilepsy remains poorly assumed [4]

Drug treatment of seizures/epilepsy at present is rather symptomatic. Drugs used for preventing the development of epilepsy or its cure are rather uncertain. Presently around 20 approved allopathic drugs and several non-pharmacological options are available to treat epilepsy, but about 30 percent of the patients are refractory to these treatment. Research is undertaken to identify newer drugs for both symptomatic and preventive therapies [5]. Due to heterogeneity and limited understanding of this disease, discovery, and development of anti-epileptic drugs is difficult [4].

Many indigenous medical plants which are safer and well tolerated are used since ages for treating neurological diseases including epilepsy. Mimosa pudica plant belonging to the family Mimosae is known as 'sensitive plant' in English and 'lajvanti' or 'chuimi' in local Hindi language. The plant is distributed throughout India in the moist locality. It is a diffuse prickly under a shrub, of about $45-90 \mathrm{~cm}$ in height. Leaves are bipinnately compound; flowers are pink with globe heads, peduncles prickly usually in auxiliary pairs all along the branches. Fruits are bristly pods, flat and straw colored consisting of 3-5 one-seeded segments [6].
Mimosa pudica contains mimosine [7] which is a toxic alkaloid. Adrenalin like substance has been identified in the extract of its leaves. Some workers have reported the presence of crocetin dimethyl easter in the extract of the plant. Roots contain tannin. Seeds contain a mucilage which is composed of d-xylose and dglucuronic acid. The plant is also reported to contain tubuline, and a new class of phytohormone 'turgorines'. Mimosa pudica leaves extract is proven to contain various bioactive components such as terpenoids, flavonoids, glycosides, alkaloids, quinines, phenols, tannins, saponins and coumarins [8].

Ayurveda has proved that its root is bitter, acrid, coolant, vulnerary, alexipharmic and used in the treatment of leprosy, dysentery, vaginal and uterine complaints, inflammations, asthma, leucoderma, fatigue and blood diseases [8]. It is also used for the treatment of anxiety and depression [9]. Alcoholic extract of Mimosa pudica leaves has been proved to possess anti-epileptic activity in previous studies [10]. Hence, the present study is undertaken with an alcoholic extract of Mimosa pudica root to explore its antiepileptic potential.

\section{MATERIALS AND METHODS}

\section{Chemicals}

Ethanol, Pentylenetetrazole (PTZ, Sigma laboratory), Propylene glycol, Valproic acid (Sun pharmaceuticals)

\section{Preparation of the extract}

Mimosa pudica plant was collected along with roots from around Mysore district and authenticated by the Pharmacognosy department of JSS Pharmacy College, Mysore. The roots were separated and made into a coarse powder after a shade dry for $1 \mathrm{w}$. About 500grams of this powder was subjected to soxhlet extraction for $12 \mathrm{~h}$ using ethanol as a solvent. The extract was further concentrated using vacuum extractor for complete removal of the ethanol. The concentrated ethanolic extract of Mimosa pudica root (EMPR) was dissolved in vehicle propylene glycol for oral administration to the animals. 


\section{Animals}

Adult Swiss albino mice of either sex weighing between 25 to $30 \mathrm{~g}$ were randomly selected from Central animal facility of JSS Medical College, Mysore. Animals were housed in 5 groups of 6 each, at an ambient temperature of $25 \pm 1^{\circ} \mathrm{C}$ with ad libitum access to food and water. The animals were fasted overnight just prior to the experiment but allowed free access to drinking water and food.

\section{Grouping}

Animals were randomly divided into 5 groups of 6 each.

Group 1: Control group received $0.25 \mathrm{ml}$ propylene glycol p. o.

Group 2: Standard group received $200 \mathrm{mg} / \mathrm{kg}$ Valproate p. o. [11]

Group 3: Test group 1-received $1000 \mathrm{mg} / \mathrm{kg}$ of EMPR p. o.

Group 4: Test group 2-received $2000 \mathrm{mg} / \mathrm{kg}$ of EMPR p. o.

Group 5: Test group 3-received $1000 \mathrm{mg} / \mathrm{kg}$ of EMPR+70 mg/kg Valproate p. o.

All the drugs were administered orally for $5 \mathrm{~d}$. The experimental seizures were induced on $5^{\text {th }}$ day of the experiment. The Institutional Animal Ethical Committee approval was obtained prior to the experimentation.

\section{Phytochemical screening}

The freshly prepared extract of the roots of Mimosa pudica was subjected to phytochemical screening tests for the detection of various constituents [12].

\section{Acute toxicity study}

The animals were treated with increasing doses of the ethanolic extract (EMP): $0.5,1,2,4$ and $5 \mathrm{~g} / \mathrm{kg} \mathrm{p}$. o. The toxicity studies were conducted according to the OECD 423 guidelines [13]. All the treated animals were observed for any abnormal or toxic manifestations and mortality.

\section{Anti-epileptic models [14]}

\section{Maximal electroshock-induced seizures (MES) in mice}

The tonic-clonic convulsions were induced by maximal electroshock using an electroconvulsiometer (INCO, Ambala, India) by passing an alternating electric current of $50 \mathrm{~Hz}$ and $150 \mathrm{~mA}$ for 0.2 seconds through ear clip electrodes. The animals were preliminarily screened and the mice which showed the extension of hind limb upon electric shock were included in the study. All the drugs and propylene glycol were administered one hour prior to induction of convulsion. The duration of tonic hind limb flexion (THLF), tonic hind limb extension (THLE), clonus and stupor were noted. The vehicle treated mice showed the characteristic extensor tonus. The abolition of extensor (tonic) phase in drug treated groups was taken as criteria for their anticonvulsant activity.

\section{Pentylenetetrazole (PTZ) induced seizures in mice}

The albino mice were selected two weeks prior to the experiment by injecting the Pentylenetetrazole in a dose of $30 \mathrm{mg} / \mathrm{kg}$ intraperitoneally. Only those mice which showed clonic convulsions within 30 min during the preliminary examination were chosen for the study. After one hour of drug treatment, PTZ $(70 \mathrm{mg} / \mathrm{kg})$ was injected intraperitoneally and animals were observed for clonic convulsion episode. The clonic convulsions onset time, duration of clonic convulsions and postictal depression were observed for a period of $30 \mathrm{~min}$.

\section{Statistical analysis}

The results were computed using GRAPH PRISM PAD version 5. One way Anova test followed by Post-hoc Tukeys multiple comparison tests were applied using the software. The differences between means were considered to be significant at $p<0.05$. The results were tabulated as below.

\section{RESULTS}

\section{Phytochemical screening}

Phytochemical screening of EMPR showed that the crude extract contained tannins, alkaloids, terpenoids, flavonoids, sterols, phenolic compounds and proteins.

\section{Acute toxicity study}

There was no mortality amongst the mice treated with the graded dose of EMPR up to a dose of $5000 \mathrm{mg} / \mathrm{kg}$ for a duration of $72 \mathrm{~h}$ EMPR dose-dependently protected the mice against the MES and PTZ induced seizures. At the dose of $500 \mathrm{mg} / \mathrm{kg}$ and $4000 \mathrm{mg} / \mathrm{kg} \mathrm{p}$. 0 , the EMPR provided respectively $23 \%$ and $100 \%$ protection against seizures in PTZ induced seizures model. Based on the preliminary toxicity data and logarithmic dose-response curve, the EMPR dose of our further study was determined between 1000 to $4000 \mathrm{mg} / \mathrm{kg}$.

\section{MES-induced seizure model}

The average duration of tonic hind limb flexion (THLF), tonic hind limb extension (THLE), clonus and stupor along with the percentages of inhibition of convulsions are presented in table 1.

Table 1: Effect of ethanolic extract of M. Pudica (EMPR) on MES-induced seizures in mice

\begin{tabular}{llllll}
\hline Group & Treatment & $\begin{array}{l}\text { Duration of } \\
\text { THLF (sec) }\end{array}$ & $\begin{array}{l}\text { Duration of } \\
\text { THLE (sec) }\end{array}$ & $\begin{array}{l}\text { Duration of } \\
\text { clonus (sec) }\end{array}$ & $\begin{array}{l}\text { Duration of } \\
\text { stupor (sec) }\end{array}$ \\
\hline I & Vehicle control & $8.45 \pm 0.57$ & $9.15 \pm 0.50$ & $\begin{array}{l}\text { \% inhibition of } \\
\text { convulsion }\end{array}$ & $\begin{array}{l}18.65 \pm 0.80 \\
--\end{array}$ \\
II & Valproate $(200 \mathrm{mg} / \mathrm{kg})$ & $3.2 \pm 0.66^{* * * *}$ & $1.98 \pm 0.28^{* * * *}$ & $9.63 \pm 1.31^{* * *}$ & $80.35 \pm 3.67^{* * * *}$ \\
III & EMPR $(1000 \mathrm{mg} / \mathrm{kg})$ & $5.7 \pm 0.57^{* *}$ & $5.27 \pm 0.14^{* * * *}$ & $13.05 \pm 1.06^{*}$ & $118.2 \pm 2.84^{* * * *}$ \\
IV & EMPR (2000 mg/kg) & $4.53 \pm 0.37^{* * *}$ & $4.36 \pm 0.42^{* * * *}$ & $12.03 \pm 1.4^{*}$ & $109.2 \pm 2.98^{* * * *}$ \\
V & EMPR+Valproate & $3.9 \pm 0.41^{* * * *}$ & $2.14 \pm 0.26^{* * * *}$ & $10.23 \pm 1.73^{* * *}$ & $92.33 \pm 3.11^{* * * *}$ \\
& $(1000 \mathrm{mg} / \mathrm{kg}+70 \mathrm{mg} / \mathrm{kg})$ & & & & $76.61 \%$ \\
\hline
\end{tabular}

Values are expressed as mean \pm SEM. Comparison between control v/s all the other groups. Statistical test done by one-way ANOVA followed by Post-hoc Tukey's multiple comparison test, ${ }^{*} \mathrm{p}<0.05,{ }^{* *} \mathrm{p}<0.01 ;{ }^{* * *} \mathrm{p}<0.001 ;{ }^{* * *} \mathrm{p}<0.0001$.

Albino mice pretreated with EMPR at the doses of 1000 and 2000 $\mathrm{mg} / \mathrm{kg}$ exhibited a significant delay in the onset time and also a significant decrease in duration of THLF, THLE, clonus and stupor phases when compared to the control group mice. The albino mice pretreated with EMPR at doses of 1000 and $2000 \mathrm{mg} / \mathrm{kg}$ also exhibited significant protection from convulsion induced by electroshock method in a dose-dependent manner. The animal group treatment with a combination of both $1000 \mathrm{mg} / \mathrm{kg}$ of EMPR and low dose $(70 \mathrm{mg} / \mathrm{kg})$ of valproate exhibited significant antiepileptic activity comparable to the Standard Valproate $(200 \mathrm{mg} / \mathrm{kg}$ ) treated group.

\section{Pentylenetetrazole (PTZ) induced seizure model}

The average seizure latency time, duration of myoclonic jerks, Generalized clonic seizures and post-ictal depression along with the percentages of protection against convulsions are presented in table 2. Albino mice pretreated with EMPR at the doses of 1000 and 2000 $\mathrm{mg} / \mathrm{kg}$ and the combination group exhibited a significant delay in the onset time of clonic seizures when compared to the control group mice. EMPR $(1000$ and $2000 \mathrm{mg} / \mathrm{kg})$ treated mice also showed a significant decrease in number and duration of myoclonic jerks, clonic seizures and duration of postictal depression when 
compared to the control group mice. EMPR provided significant protection from convulsion induced by PTZ in a dose-dependent manner. The animal group treatment with a combination of both
$1000 \mathrm{mg} / \mathrm{kg}$ of EMPR and low dose $(70 \mathrm{mg} / \mathrm{kg})$ of valproate exhibited a significant anti-epileptic activity even better than the Standard Valproate $(200 \mathrm{mg} / \mathrm{kg})$ treated group.

Table 2: Effect of ethanolic extract of M. Pudica L. (EMPR) on PTZ induced seizures in mice

\begin{tabular}{|c|c|c|c|c|c|}
\hline $\begin{array}{l}\text { Group- } \\
\text { treatment }\end{array}$ & $\begin{array}{l}\text { Seizure latency } \\
\text { period (sec) }\end{array}$ & $\begin{array}{l}\text { Duration of-of myoclonic } \\
\text { jerks (sec) }\end{array}$ & $\begin{array}{l}\text { Duration of clonic seizures } \\
\text { (sec) }\end{array}$ & $\begin{array}{l}\text { PID } \\
\text { (sec) }\end{array}$ & $\begin{array}{l}\% \\
\text { Protection }\end{array}$ \\
\hline I-Vehicle control & $308.6 \pm 25.81$ & $6.72 \pm 0.48$ & $14.2 \pm 0.66$ & $322.6 \pm 9.82$ & -- \\
\hline II-Valproate & $483 \pm$ & $1.68 \pm 0.21 * * * *$ & $8.12 \pm$ & $232.57 \pm$ & $56.51 \%$ \\
\hline (200 mg/kg, p. o) & $22.72^{* * * *}$ & & $0.66^{* * * *}$ & $14.35^{* * * *}$ & \\
\hline III-EMPR & $404.5 \pm$ & $3.51 \pm 0.26^{* * * *}$ & $10.98 \pm$ & $291.33 \pm$ & $31.1 \%$ \\
\hline (1000 mg/kg, p.o) & $17.49 *$ & & $0.32 * *$ & 9.34 & \\
\hline IV-EMPR & $510.7 \pm$ & $1.13 \pm 0.17^{* * * *}$ & $8.65 \pm$ & $213.3 \pm$ & $65.48 \%$ \\
\hline (2000 mg/kg, p.o) & $22.74^{* * * *}$ & & $0.24^{* * * *}$ & $8.2^{* * * *}$ & \\
\hline V-EMPR+Valproate & $554.3 \pm$ & $1.02 \pm 0.21 * * * *$ & $5.059 \pm$ & $190.5 \pm$ & $79 \%$ \\
\hline $\begin{array}{l}(1000 \mathrm{mg} / \mathrm{kg}+ \\
70 \mathrm{mg} / \mathrm{kg}, \text { p. o) }\end{array}$ & $11.77^{* * * *}$ & & $0.66^{* * * *}$ & $5.1^{* * * *}$ & \\
\hline
\end{tabular}

Values are expressed as mean \pm SEM. PID: Postictal depression; Comparison between control vs all the other groups. Statistical test is done by oneway ANOVA followed by Post-hoc Tukey's multiple comparison tests. ${ }^{*} \mathrm{p}<0.05,{ }^{* *} \mathrm{p}<0.01 ;{ }^{* * *} \mathrm{p}<0.001 ;{ }^{* * * *} \mathrm{p}<0.0001$.

\section{DISCUSSION}

Epilepsy is a group of chronic neurological disorder characterized by episodes of convulsive seizures, sensory disturbance, altered consciousness or all of these symptoms resulting from a brain dysfunction or an abnormal discharge of cerebral neurons [15]. The currently available AEDs for the therapy of epilepsy are associated with various side effects like teratogenicity and chronic toxicities of various organs. This has necessitated the need for a safer alternative indigenous drugs for the pharmacotherapy of epilepsy.

Various plant preparations are used by the folklore and the tribals for the treatment of common disease conditions including epilepsy. Mimosa pudica is one of those commonly seen plants which is known to possess analgesic, anti-anxiety, antidepressant, anti-asthmatic and aphrodisiac properties [8]. Phytochemical screening of the EMPR extract revealed the presence of tannins, alkaloids, terpenoids, flavonoids, sterols, phenolic compounds and proteins.

The data obtained from the present study demonstrated that EMPR significantly inhibited the convulsions induced by MES and PTZ. GABA is known to be a major inhibitory neurotransmitter in the brain and glutamate the excitatory neurotransmitter. GABA acts on GABA receptors while glutamate acts on NMDA and non-NMDA receptors. These receptors are known to modify various ion channels like $\mathrm{Na}^{+}, \mathrm{K}^{+}, \mathrm{Ca}^{++}$or Cland thereby influence the neuronal activity [16]. Abnormalities in the GABAergic system have been implicated in various neurological and psychological diseases such as anxiety, panic attacks, schizophrenia, huntington's chorea and epilepsy. Decreased function of $\mathrm{GABA}_{\mathrm{A}}$ synapses is known to be one of the important factors for epileptogenesis [14].

MES test in mice primarily indicates the compounds which are effective in grand mal epilepsy. The tonic extension of the hind limb evoked by electrical stimuli is suppressed by anti-epileptics. Antiepileptic drugs that block MES-induced seizure are known to act by blocking the seizure spread [17]. The drugs which antagonize the PTZ induced convulsions are known to be effective in petitmal epilepsy. PTZ is known to possess GABA antagonistic activity [18] The antiepileptic drugs diazepam and phenobarbitone are proved to produce their antiepileptic effects by enhancing GABA-mediated inhibition in the brain. Valproate is known to act by multiple mechanisms: prolongation of $\mathrm{Na}^{+}$channel inactivation-like phenytoin, attenuation of T-type $\mathrm{Ca}^{++}$currents like ethosuximide and by augmenting GABA transmission. It is known to inhibit both PTZ and MES-induced convulsions [19].

Previous studies have demonstrated the antiepileptic activity of decoction of Mimosa pudica leaves at the doses of 1000-4000 mg/kg i. $p$ in pentylenetetrazole and strychnine induced seizure models [20]. Also in another study, an alcoholic extract of leaves of Mimosa pudica in the dose of 50,100 and $200 \mathrm{mg} / \mathrm{kg}$ given orally suppressed the MES-induced seizures in albino rats [10].
The present revealed that EMPR possesses a dose-dependent protection against-tonic extensor phase in MES-induced seizure model and seizure latency in PTZ induced seizure model. EMPR showed a better anticonvulsant activity in the PTZ model than MES anti-epileptic model. The EMPR combined with the low dose of valproate $(70 \mathrm{mg} / \mathrm{kg})$ showed a similar anticonvulsant activity as the standard dose of valproate $(200 \mathrm{mg} / \mathrm{kg})$. This combination of low doses of EMPR and Valproate is beneficial as it reduces the incidences and severity of undue side effects of the drugs.

The phytochemical screening of the extract revealed the presence of tannins, alkaloids, triterpenoids, flavonoids, sterols, phenolic compounds and proteins. Based on the present knowledge of the chemical constituents it is not possible to attribute with certainty the detected active principle/s for its anticonvulsant activity. However, several flavonoids could act as benzodiazepine-like molecules in the central nervous system and modulate GABAmediated chloride channels in animal models of anxiety, sedation and convulsion. Certain triterpenic steroids are reported to possess anticonvulsant activity in MES and PTZ experimental seizure models [21]. Further studies are required for isolation of bioactive principles responsible for these activities. These findings justify the traditional use of this plant in the control and treatment of convulsions and epilepsy.

\section{CONCLUSION}

It can be concluded from the study that the ethanolic extract Mimosa pudica root (EMPR) exhibited significant antiepileptic activity in both MES and PTZ induced seizure models. Further studies are needed to evaluate the precise mechanism/s, bioactive principles and safety profile of the plant as a medicinal remedy for convulsive disorders.

\section{CONFLICT OF INTERESTS}

Declared none

\section{REFERENCES}

1. Sander JW, Shorvon SD. Epidemiology of the epilepsy. J Neurol Neurosurg Psychiatry 1996;6:433-43.

2. Ngugi AK, Bottemley C, Kleinschmidt I. Estimation of the burden of active and life-time epilepsy: a meta-analytic approach. Epilepsia 2010;51:883-90.

3. Porter RJ, Meldrum BS. Antiseizures drugs. In: Katzung BG, Masters SB, Trevor AJ. Basic and Clinical Pharmacology. 11th ed. New Delhi: Tata-McGraw Hill; 2009. p. 399-400.

4. Lowenstein DH. Seizures and epilepsy. In: Fauci, Braunwald, Kasper, Hauser, Longo, Jameson. Harrisons Principles of Internal Medicine. 17th ed. USA: McGraw Hill; 2008. p. 2498-9.

5. McNamara JO. Pharmacotherapy of epilepsies. In: Brunton LL, Lazo JS, Parker KL. Goodman and Gillman's the 
Pharmacological Basis of Therapeutics. 11th ed. USA: McGraw Hill; 2006. p. 501-4.

6. Chauhan, Bhagirath S, Johnson, Davi E. Germination, emergence and dormancy of Mimosa pudica. Weed Biol Manag 2009;9:38-45.

7. Tamilarasi T, Ananthi T. Photochemical analysis and microbial activity of Mimosa pudica activity. Res J Chem Sci 2012;2:72-4.

8. Baby Joseph, Jency George, Jeevitha Mohan. Pharmacology and traditional uses of Mimosa pudica. Int J Pharm Sci Drug Res 2013;5:41-4.

9. Srivasthava Varnika, Sharma Ashish, Alam Imran. A review on ethnomedical and traditional uses of Mimosa pudica. Int Res J Pharm 2012;3:41-4.

10. Naveen Alasyam, Mannala Sunil, $\mathrm{T}$ Jayasree, K Vinay Kumar, Ch Nagesh, Narapogu Venkatanarayana. Evaluation of the anticonvulsant activity of alcoholic extract of Mimosa pudica in swiss albino rats. J Chem Pharm Res 2014;6:1175-9.

11. Maignana kumar R, Ruckmani A, Saradha S, Arunkumar R, Lakshmipathy prabhu R, Madhavi E, et al. Evaluation of the antiepileptic activity of Vetiveria zizanioides oil in Mice. Int J Pharm Sci Rev Res 2014;25:248-51.

12. Harbone JB. Phytochemical methods. a guide to modern techniques of plant analysis. 2nd Ed. Chapman and Hall, London; 1984. p. 274-84.

13. OECD Guidance Document on Acute Oral Toxicity. Environmental Health and Safety Monograph Series on Testing and Assessment; 2001.

14. Vogel HG. Anticonvulsant activity. In: Vogel WH, Scholkens BA, Sandow J, Muller G, Vogel WF. Drug discovery and evaluation pharmacological assays. 2nd ed. New York: Springer Press; 2002. p. 423-87.

15. Jerome E, Timothy AP. A Comprehensive Textbook. 2nd ed. Philadelphia: Lippincott Williams and Wilkins: What is Epilepsy; 1997. p. 1-7.

16. Satoskar RS, Bhandarkar SD. 12th ed. Mumbai: Popular Prakashan Pharmacology and Pharmacotherapeutics; 1991. p. 10

17. Rogawski MA, Porter RJ. Antiepileptic drugs: pharmacological mechanisms and clinical efficacy with consideration of promising development stage compounds. Pharmacol Rev 1990;42:223-86.

18. De Sarro A, Cecchetti V, Fravoloni V, Naccari F, Tabarrinia O, De Sarro G. Effects of novel 6-desfluoroquirolones and classic quinolones on pentylenetetrazole-induced seizure in mice. Antimicrob Agents Chemother 1999;43:1729-36.

19. Tripathi KD. Essentials of medical pharmacology. $7^{\text {th }}$ ed. New Delhi. Jaypee Publishers; 2013. p. 417.

20. Ngo Bum E, Dawack DL, Schmutz M, Rakotonirina A, Rakotonirina SV, Portet C, et al. Anticonvulsant activity of Mimosa pudica decoction. Fitoterapia 2004;75:309.

21. Kasture VS, Kasture SB, Chopde CT. Anticonvulsive activity of Butea monosperma flowers in laboratory animals. Pharmacol Biochem Behav 2002;72:965-72.

\section{How to cite this article}

- Prathima C, Shashikumara, Thippeswamy T, Jayanthi MK Evaluation of the anticonvulsant activity of mimosa pudica root linn in swiss albino mice. Int J Pharm Pharm Sci 2016;8(9):49-52. 